\title{
Translator: Expert of 'What'? \\ Translator Training and the Changing/Changeful Identity of the Translator
}

\author{
Senem Öner*
}

\begin{abstract}
The aim of this paper is to trace the contemporary perceptions/definitions of the translator and translation in Turkey where the translation profession is not a legally regulated profession. (In)visibility of the translator and the scope of his/her expertise are widely debated issues among both the scholars/students of translation and the various players in the world of translation. Although translation is no longer being defined as a mere linguistic activity, reductionist views of translation that equate translation to 'know'ing a foreign language still continues to prevail. What accompanies the said reductionist view is the claim that a translator can not translate 'all the texts' in different fields of expertise, at least not as successfully as the 'real' experts of the field who also know a foreign language such as engineer-translators or lawyer-translators who know English. However, recent developments concerning legal translation in plurilingual settings evidence a completely different understanding of translation and the identity/expertise of the translator. In such settings, translators work together with the drafters of the legal texts and are responsible for the source legal texts as well as the target ones, broadening the scope of the 'expertise' of the translator in an unprecedented way. In the light of the implications of the said transformation of the identity of the legal translator, this paper argues that the identity/definition of the translator/translation

\footnotetext{
* Instructor, Faculty of Science and Letters / Translation and Interpretation, İstanbul Arel University
} 
needs to be reconsidered and the results should be reflected onto the translator training programs with the aim of helping students of translation (re)define their identity as real 'experts' of the translation field and contributing to the transformation of the perception of translation and the translator.

Keywords: Translator training, Identity of the translator, Legal translation, Translation profession.

\section{Introduction}

(In)visibility of the translator (Venuti, 1995) and the scope of his/her expertise are widely debated issues among both the scholars/students of translation and the various players in the world of translation. In Turkey where the translation profession is not a legally regulated/protected one, there seems to be serious confusion as to the definition of translation and translation profession. Drawing on these facts, this paper aims to trace the contemporary perceptions/definitions of translation in Turkey with a focus on the potential contribution of translator training institutions to the resolution of the said confusion.

\section{Tracing the Perception(s) of Translation and the Translator}

A striking translation case that gives clues about the perception of translation and the translator and the above mentioned confusion is the debate Turkey witnessed on a translation in 2006. The translation of Georges Perec's La Disparition (Kayboluş) by Cemal Yardımcı into Turkish occupied the agenda and the translator was harshly criticized on the grounds that he intervened in the original. What made Yardimc the target of criticism was his "intervention": he omitted certain parts of Perec's text and added new ones in the translation, because of "numerical necessities" (Yard1mc1, 2006) in his own words. The severe wave of criticism he faced was revealing with respect to the perception of translation/the translator in Turkey.

The discourse of the critics about the translation/translator implied a rigid distinction between original and translation, between author and translator. Taking "faithfulness" as the main and only goal of the translation process, the critics involved in the debate were irritated by the intervention or visibility of the translator. According to Celal Üster who was very much annoyed at the intervention of the translator, for instance, a translator "can not change even a word of the text s/he translates" (Üster, 2006a, my emphasis). Again according to Üster, what Cemal Yardımcı did was "transforming the book of Perec into another book" (Üster, 2006b). Another critic, Ferit Edgü who "could not believe" that Yardımcı added a part

\footnotetext{
${ }^{1}$ Unless otherwise indicated, all translation are mine.
} 
to Perec's novel defined the translational practice of Yardimc1 as "craziness" and "absurdity" (Edgü in Atmaca, 2006). The same line of thought was also present in the discourse of other critics such as Tahsin Yücel who argued that "a translator should remain faithful to a text s/he translates as much as possible" (Yücel in Atmaca, 2006) and Tuncay Birkan, according to whom "the translator is essentially responsible to the text s/he translates and every good translator should be aware of this" (Birkan in Atmaca, 2006).

The essentialist language which downgrades translation/translator as opposed to original/author dominated the discourse of the critics. They all wished to debar the translator from exerting authorial rights. However, whether consciously or unconsciously, the same critics also mentioned the existence of interpretation in translation and in some cases they defended that a translator can interpret or should inevitably interpret the original.

As mentioned above, Yardımcı was accused of being "unfaithful" to the original, committing additions and omissions hence "interventions". However, in the same discourse of those critics who accused the translator emerged a point where the consistency of their discourse broke down and where an inconsistency was uncovered which, I think, could be defined as 'the question of limit'.

By 'limit' I refer to the boundaries (as drawn randomly by critics) beyond which a translator can not exert any kind of authorial right. What renders the issue of limit problematic is especially the fact that it is determined without any criteria, very personally and the critics who allowed the translators to "intervene" within certain limits and prohibited to do so beyond that limits do not bother themselves with justifying their choices. For instance, Celal Üster, the sharpest among all other critics, criticized Celal Yardımcı for "adding four parts to the text of Perec", "changing the titles" and "transforming the book of Perec into another one" on the grounds that a translator "can not change even a word of the original" (Üster, 2006b). However, this seemingly consistent attitude broke down when it came to the issue of interpretation and poetry translation as a special kind of translation:

"Kimi kitapların çevirisi, belirli bir uyarlamayı gerektirebilir. Kimi çevirmenler de çevirdikleri yazara bir hayli müdahale ederek onu iyice 'bizden' kılarlar....Şiir çevirisinin 'özgür' bir yaklaşımı bir ölçüde kaldırdığını, dahası bazen kaçınılmaz kıldı̆̆ını söyleyebilirim.” (Üster 2006b, my emphasis)

[Translation of some books may necessitate a certain degree of adaptation. Some translators intervene in (the work of) the author they translate to a great extent and make the author thoroughly our "own"... I can say that poetry translation tolerates a "free" approach to some extent, even renders it inevitable at times.] 
So, according to Üster who takes pains to defend a "word for word" or "faithful" translation, the translation of "some" books may necessitate "a certain degree of adaptation", moreover in "some" cases a "free" approach is inevitable. Another example is Tuncay Birkan's criticism:

"Her iyi çevirmenin bir damgası vardır aslında. O damgayı örneğin bölümler ekleyerek, kitapta olmayan üslubu kitaba dayatarak fazla öne çıkarmak gayrimeşru şeylerdir. Çevirmenin asli sorumluluğu metine karşıdır ve bütün iyi çevirmenler bunun farkında olmak zorundadır. Elbette çevirmenin yaratıcı bir şahsiyet olduğunu gözden kaçırmamak şart. Dengeli ve ölçülü olmaya çalışmak gerekir. Bu soruşturmaya konu olan vakada ölçünün biraz kaçtığı görülüyor.” (Atmaca 2006, my emphasis)

[In fact every good translator has a stamp. It is illegitimate to emphasize that stamp too much by, for instance, adding parts or imposing a style which does not exist in the book. The translator is essentially responsible for the text and all good translators should be aware of this fact. Of course we should not overlook that translator is a creative figure. A translator should try to be balanced and measured. In this case the translator a little crossed the line.]

Birkan's criticism is also marked by all the features of an essentialist, prescriptive approach and displays an inconsistency observed most explicitly when he talks about limits. $\mathrm{He}$ at the same time underlines the translator's stamp and an illegitimate degree of emphasizing that stamp, the translator's creativity and going beyond the limit without explaining how and by whom the limit or degree is to be determined. This inconsistency is revealing with respect to the obsession with the original and the irritation caused by the inevitability of interpretation and the role of the translator as an individual/social agent who makes decisions consciously and unconsciously (Basile, 2005) and who is the expert (Vermeer, 2000) in the translation situation.

Indeed, the question of limit and the accompanying inconsistency are closely related to the contradiction Işın Bengi-Öner observes in prescriptive, source-oriented approaches to translation. Bengi-Öner argues that since source-oriented approaches focus on the "source", they are disconnected from realities of translation, which in turn converts them into a set of contradictory rules and that all the theories developed in the period from the 2 nd century BC to the first half of the 20th century are source-oriented and prescriptive and contradiction is a distinctive feature thereof (Bengi-Öner, 1999: 116). She depicts the contradiction in question and the resulting uneasiness felt by the translator as follows:

"Bu kuramların ayrılmaz bir parçası olan çelişki özellikle çeviri eleştirisi alanında açık olarak kendini göstermektedir. Süreç-ağırlıklı, kaynak-odaklı ve kuralcı kuramlar çerçevesinde yapılan çeviri eleştirisinde, eleştirmen çeviri gerçekleriyle hiçbir bağı olmayan eleştirel görüşlerini ve beğenisini adeta çeviride ulaşılması mümkün ve 
değişmez özellik gösteren bir düzey varmışçasına (ama bu düzeye ilişkin bütünlük içinde somut örnek vermeden) sunmaktadır. Bu tür eleştirilerle karşı karşıya kalan ve hep 'eksikli' durumda olan çevirmen ise kendisinden ne beklendiğini doğal olarak anlayamamaktadır. Bu tavır, söz konusu kuramların özünde varlığını sürdüren çelişkinin, çeviri eleştirisine yansımasından başka bir şey değildir.” (117)

[As an integral part of these theories, contradiction is manifest especially in the field of translation criticism. When criticizing a translation within the frame of processoriented, source-oriented and prescriptive theories, the critic expresses his/her views and preferences, which are completely disconnected from realities of translation, in such a way as if there exists an attainable and invariable level in translation (but without giving concrete examples of this level in an entirety). The translator who faces with such kind of criticism and finds himself/herself in a defective state all the time and cannot understand what is expected of him/her. This attitude is nothing but the reflection of the contradiction that continues to exist in the very essence of these theories onto translation criticism.]

Since this source-oriented approach to translation and the translator still prevails, the translators are still denied from the rights reserved for authors without any clarification regarding the scope of their expertise and it is still easy to 'judge' translators as compared to other professionals who are members of professions regulated and protected by the law and on the scope of which exists a clear consensus among the parties concerned.

Although translation is no longer being defined as a mere linguistic activity, reductionist views of translation that equate translation to 'knowing' a foreign language also continue to exist. What accompanies this reductionist view is the claim that a translator can not translate 'all the texts' in different fields of expertise, at least not as successfully as the 'real' experts of the field who also know a foreign language such as engineer-translators, lawyer-translators or doctor-translators who know a foreign language. Two examples from the contemporary translation sector in Turkey attest to the said fact. The following passage on translation quality taken from the website of a translation company is significant in terms of the perception of translation and the confusion concerning the scope of translator's expertise:

"Tercümeleriniz, konusunda en az 5 yıl tecrübeli, titizlikle seçilmiş olan tercüman arkadaşlarımız tarafından yapılmaktadır. Tercümanlarımızın çoğu kendi alanlarında uzman olup öğretmen, avukat, doktor, ... vs. gibi en az bir meslek sahibidirler. Bu bağlamda size tercüme kalitesi konusunda garanti verilir." (Tercumix, my emphasis)

[Our translations are produced by our translator friends who have at least five-year experience in their fields and who are selected carefully. Most of our translators are 
experts in their respective fields and have a profession such as teacher, lawyer, doctor etc. In this context, we guarantee that our translations are of high quality.]

The above passage is a striking evidence of the fact that translation profession is not considered as a profession per se. Especially ironic is the company's claim that the underlying reason for its success is that they work with "translators who have at least one profession." It is also inferred from the passage that being merely a translator cannot guarantee high-quality translation for which a 'real' profession is required. This perception of translation/the translator is also manifest in the following passage taken from the website of another translation company where it is claimed that the success of the company in technical translation depends on engineer-translators:

"En iddialı olduğumuz tercüme konularının başında teknik çeviri gelmektedir. Teknik çeviri, diğer çeviri konulardan ayrı olarak ele alınması gereken, dilin yanı sıra mesleki uzmanlık da gerektiren bir konudur. Rota Tercüme Bürosu teknik çevirileri, çeşitli konularda mühendislik özgeçmişine sahip tercümanlar koordinatörlüğünde gerçekleştirir. Dilin yanı sıra mesleki bilgilerin de çevirilerde hissedilmesi müşterilerimizin bizi tercih etmelerinde önemli etkendir. Teknik çeviri için uyguladığımız bu yöntem Rota Tercüme Bürolarını diğer çeviri bürolarından ayıran önemli özelliklerin başında gelir" (Rota Tercüme)

[Technical translation is one of the fields we are most ambitious about. Technical translation is an issue that should be handled separately from other translation issues and requires professional expertise as well as language. In Rota Tercüme Bürosu, technical translations are produced under the coordination of translators who have worked as engineers in different fields. In addition to language, professional knowledge is felt in our translations and this significantly contributes to our reputation as a preferred company. This method applied in technical translations is what differentiates us from other translation companies.]

In the above passage there is an assumed differentiation between non-technical translation and technical translation which, according to the company, necessitates the coordination of engineer-translators. Related to this differentiation is the company's claim that professional expertise of the engineer-translators is an additional qualification that makes the company a preferred one with regard to technical translation. What is especially significant about this claim is the inferred view of translation and the translator, according to which a translator might not be adequate for translating a technical text if he/she is not an engineer at the same time. The distrust to "mere translators" implied in this view can also be said to prevail heavily in the translation sector in Turkey and, I believe, stems from the 
ignorance of the 'real' scope of the translator's expertise which could only be clarified with the aid of the target-oriented approach to translation.

\section{Translator: Expert of 'What'?}

Thanks to the developments in the field of translation beginning in 1970s and to the unprecedented target-oriented approach to translation and the translator, the perception of these has undergone a radical transformation. Shifting the focus from the source text/language/culture to the target text/language/culture, the target-oriented approach has brought up a fresh look to translation phenomena. Among the many scholars in this line, the approach of Hans J. Vermeer, one of the leading scholars in the field of translation studies, to the issue of expertise in the context of translation is crucial for this study. Vermeer clearly posits the translator as the "expert" within the frame of his skopos theory and a functional approach to translation:

"The translator is 'the' expert in translational action. He is responsible for the performance of the commissioned task, for the final translation. Insofar as the duly specified skopos is defined from the translator's point of view, the source text is a constituent of the commission, and as such the basis for all the hierarchically ordered relevant factors which ultimately determine the translatum. ...

As regards the translator himself: experts are called upon in a given situation because they are needed and because they are regarded as experts. It is usually assumed, reasonably enough, that such people "know what it's all about"; they are thus consulted and their views listened to. Being experts, they are trusted to know more about their particular field than outsiders. In some circumstances one may debate with them over the best way of proceeding, until a consensus is reached, or occasionally one may also consult other experts or consider further alternative ways of reaching a given goal. An expert must be able to say-and this implies both knowledge and a duty to use it-what is what. His voice must therefore be respected, he must be 'given a say'. The translator is such an expert. It is thus up to him to decide, for instance, what role a source text plays in his translational action.

The decisive factor here is the purpose, the skopos, of the communication in a given situation. (Cf. Nord 1988:9.)" (Vermeer, 2000: 222, my emphasis)

I believe the above view of the translator needs to be strongly emphasized both in translator training institutions and in every interaction with those interested or have a stake in translation. This would contribute to the transformation of the above discussed perceptions of translation and especially the translator which entail distrust towards the translator and/or do not recognize him/her as an expert, the expertise of whom, in fact, includes inter- 
lingual/cultural communication, translation-oriented text analysis and research, text production and all the techniques required in the pre-translation, translation and posttranslation processes.

However, there is still room for optimism. Despite the dominance of the 'narrow' view of translation and the translator sketched above, recent developments concerning legal translation in plurilingual settings evidence a completely different understanding of translation and of the identity/expertise of the translator. In such settings, translators work together with the drafters of the legal texts and are responsible for the source legal texts as well as the target ones, broadening the scope of the 'expertise' of the translator in an unprecedented way. In her comprehensive overview of the guidelines for legal translation beginning from the Roman Empire up to contemporary era, Susan Šarčević depicts the changing role and status of the legal translator in accordance with the changing circumstances affecting legal translation. She underlines that "word for word translation" or "strict literal translation" was the only recognized strategy of legal translation for a long period of time and this faithfulness-oriented tradition has started to change with the notion of "legal equivalence" which requires the legal translator to produce a text "that will lead to the same legal effect" (Šarčević 2000: 25, 71) instead of a "word for word" copy of the source text, especially in the context of bilingual and plurilingual legal practices where the translations of one source text in different languages are considered "equally authentic" and desired to provide "uniform interpretation and application" (121). Šarčević also states that the goal of achieving uniform interpretation and application has led to the incorporation of the legal translator "into the legislative process, entrusting him/her with new authority and responsibility" by which "for the first time, the translator was given limited authority to take part in the production of the source text", "transforming the translator into a text producer and ultimately a co-drafter" (97-98, my emphasis).

In terms of the point I am making in this paper, the transformation of the identity of the legal translator is a critical example demonstrating the changing identity of the translator in two senses: change in historical continuum and change as an intrinsic part of the translator's identity which is a changeful one. The change observed in the historical transformation of the legal translator from 'a mere copier of the source text' into 'an expert involved in the production of the source legal text as well as its translation' displays, on one hand, how spatio-temporal factors shape the strategies to be used by the translator and hence his/her identity/role. It displays, on the other hand, the changeful skills the translator might be required to possess as a part of his/her expertise. I believe this is the burning fact that needs to be recognized and internalized by all the players in the world of translation. 
If the above discussed cases concerning the perception of the translation and the translator are considered from this point of view, the critics in the first case irritated by the interpretation committed by the translator can be said to be unaware of the fact that a trained literary translator, inevitably acts, thinks and writes as an author and has the freedom and responsibility of taking all the necessary measures and making decisions in accordance with the skopos of the translation determined by means of his/her knowledge and expertise. The same holds true also for the discourse of the two translation companies with distrust to "mere translators' and the implication that 'mere translators' lack the required skills for the translation of a text in the field of engineering, which can be duly done with engineers having language skills. This approach is also the outcome of an unawareness of the fact that a trained technical translator does not need to be an engineer in order to translate an engineering text, for he/she possesses the required text analysis, terminology research and technical text production skills and it is up to him/her to decide when it is necessary to consult an engineer if need be. Moreover, this is what trained translators do when they translate advertising texts, scientific texts, information technology texts, news and media texts, poems, plays, stories and novels, medical texts, automotive texts, games etc. A trained translator knows that he/she is required to think, feel, act and write as an advertiser when translating an advertising text, as a journalist when translating a news text and as a poet when translating a poem. However, above and after all, he/she is the translator who is trained to become an expert in communication. Thinking, feeling, acting and writing as the experts of various fields for translation hence communication purposes are included in the translator's scope of expertise. This should not mean that specialization in one or more fields in translation is unnecessary, however, I think, it should be borne in mind that translator training institutions are essentially responsible for helping translation students develop a core specialization in acting in accordance with the changing requirements of different fields and sub-fields of specialization and the necessary skills to carry out the required processes of different translation/communication situations.

In the light of the above considerations, I believe the perception of the identity/definition of the translator/translation needs to be reconsidered and the results should be reflected to the translator training programs with the aim of helping students of translation (re)define their identity as real 'experts' of the translation field and contributing to the transformation of the perception of translation and the translator. Translator training institutions should speak out about this fact with a louder voice. I think it is only in this way will it be possible to raise awareness about and transform the perception of translation and the translator in a profound way, contribute to the establishment of translation profession for the sake of translators who are tired of answering and confronting questions and criticism as to the scope of their profession, expertise and identity and to ensure that the translator's "voice is respected" (Vermeer, 2000: 222). 


\section{References}

Atmaca, Efnan (2006) "Çevirmen Yar1-Yazar mı?”

Available: http://www.radikal.com.tr/haber.php?haberno=179629. (accessed 10 May 2013).

Basile, Elena (2005) "Responding to the Enigmatic Address of the Other: A Psychoanalytical Approach to the Translator's Labour". New Voices in Translation Studies 1.

Bengi-Öner, Işın. (1999). Çeviri Bir Süreçtir... Ya Çeviribilim? İstanbul: Sel.

Rota Tercüme Available:

http://www.rotatercume.com/index.php?ceviri=\%C7eviri\%20Rotas\%FD\&konu=6 (accessed 10 May 2013).

Šarčević, Susan (2000) New Approach to Legal Translation. The Hauge, London, Boston: Kluwer Law International.

Tercumix. Available: (http://www.tercumix.com/yazili-tercume-ceviri.html) (accessed 10 May 2013).

Üster, Celal (2006a) "Önyargıya Karşı Yaratıcı Çeviri."

Available: http://www.radikal.com.tr/ek_haber.php?ek=ktp\&haberno=4818 (accessed 10 May 2013).

(2006b) "Perec'in Kayboluş'u mu, kayboluşu mu?"

Available: http://www.radikal.com.tr/ek_haber.php?ek=ktp\&haberno=4927 (accessed 10 May 2013).

Venuti, Lawrence (1995) The Translator's Invisibility: A History of Translation. London and New York: Routledge.

Vermeer, Hans J. 2000. "Skopos and Commission in Translational Action" in Lawrence Venuti. ed. The Translation Studies Reader. London ve New York: Routledge.

Yardımc1, Cemal (2006) “Okur Bekleniyor!” Available:

http://www.radikal.com.tr/ek_haber.php?ek=ktp\&haberno=4969 (accessed 10 May 2013). 